\title{
Development of Psychomotor Functions in Preschool Children With Intellectual Disabilities Through The Means of Correctional Eurhythmics
}

\section{Desarrollo de las funciones psicomotoras en niños en edad preescolar con discapacidad intelectual a través de la euritmica correccional}

\section{S.V. Arkhipova}

Mordovian State Pedagogical University, Saransk, Russia

ORCID: https://orcid.org/0000-0002-6241-6111

M.S. Podshivalova

Mordovian State Pedagogical University, Saransk, Russia

ORCID: https://orcid.org/0000-0002-3718-7599

*Correspondence

Email: arhipova.swetlana2011@yandex.ru
Cite as:

$$
\begin{aligned}
& \text { Arkhipova, S.V., \& Podshivalova, M.S. (2021). Development } \\
& \text { of Psychomotor Functions in Preschool Children With } \\
& \text { Intellectual Disabilities Through The Means of Correctional } \\
& \text { Eurhythmics. Propósitos y Representaciones, 9(SPE2), e984. } \\
& \text { Doi: http://dx.doi.org/10.20511/pyr2021.v9nSPE2.984 }
\end{aligned}
$$




\section{Summary}

Introduction: The article examines the problem of psychomotor development of preschool children with intellectual disabilities. The researched problem affects learning, upbringing, and socialization of children of said category and its resolution requires implication of not only traditional but also non-traditional tools including correctional eurhythmics. The goal of the study is to develop the organizational and methodical basis for the development of psychomotor functions in preschool children with intellectual disabilities through the means of musical rhythmic exercises.Materials and methods: The basis of the research is formed by general scientific cognition methods: analysis, synthesis, comparison, generalization; pedagogical experiment (ascertaining, forming, control), and empirical data analysis. The data acquired in the course of the study were processed in Excel via the methods of mathematical statistics. Results: The conducted study demonstrates a positive dynamic in the development of psychomotor functions in preschoolers with intellectual disabilities before and after conducting experimental work using the means of correctional eurhythmics. Discussion and conclusion: The collected data confirms that specially organized work using musical rhythmic games and exercises effectively contributes to the level of development of psychomotor functions in children with intellectual disabilities not only in the motor but also in the cognitive and emotional and volitional components. The prepared materials can be used by specialists and teachers of preschool education organizations interested in the development of psychomotor functions in preschool children with intellectual disabilities by the means of correctional eurhythmics.

Keywords: development, psychomotor functions, correctional eurhythmics, preschool children with intellectual disabilities.

\section{Resumen}

Introducción: El artículo examina el problema del desarrollo psicomotor de niños en edad preescolar con discapacidad intelectual. El problema investigado afecta el aprendizaje, la crianza y la socialización de los niños de dicha categoría y su resolución requiere la implicación no solo de herramientas tradicionales sino también no tradicionales, incluida la euritmia correccional. El objetivo del estudio es desarrollar la base organizativa y metódica para el desarrollo de las funciones psicomotoras en niños en edad preescolar con discapacidad intelectual a través de ejercicios rítmicos musicales.Materiales y métodos: La base de la investigación está formada por métodos de cognición científica general: análisis, síntesis, comparación, generalización; experimento pedagógico (determinación, formación, control) y análisis de datos empíricos. Los datos adquiridos en el curso del estudio se procesaron en Excel a través de los métodos de estadística matemática. Resultados: El estudio realizado demuestra una dinámica positiva en el desarrollo de las funciones psicomotoras en preescolares con discapacidad intelectual antes y después de la realización de un trabajo experimental utilizando los medios de la euritmia correccional. Discusión y conclusión: Los datos recopilados confirman que el trabajo especialmente organizado mediante juegos y ejercicios musicales rítmicos contribuye eficazmente al nivel de desarrollo de las funciones psicomotoras en niños con discapacidad intelectual no solo en los componentes motor sino también cognitivo, emocional y volitivo. Los materiales elaborados pueden ser utilizados por especialistas y docentes de organizaciones de educación preescolar interesados en el desarrollo de las funciones psicomotoras en niños en edad preescolar con discapacidad intelectual mediante la euritmia correccional.

Palabras clave: desarrollo, funciones psicomotoras, euritmia correccional, niños en edad preescolar con discapacidad intelectual. 


\section{Introducción}

The modern stage of modernization of the education system is characterized by specialists' increased attention to children with disabilities whose specific psychophysiological development characteristics significantly complicate the process of their learning, upbringing, and socialization. However, ensuring optimal conditions for their education and integration into society currently presents one of the crucial objectives of pedagogical practice the importance of which is designated by the Law of the Russian Federation "On Education in the Russian Federation" and Federal State Educational Standards (Bobkova et al., 2019).

The term "children with disabilities" refers to children in which the development of mental functions deviates from the norm due to a congenital defect or acquired organic damage to sensory organs, the musculoskeletal system, or the central nervous system (Arkhipova et al., 2018). Therefore, this group includes children with various developmental disorders including intellectual disabilities.

One of the key aspects impeding correctional and pedagogical work with this category of children is the underdevelopment of their psychomotor functions.

Motor clumsiness, uncoordinated movements, low motor switchability, distortion of spatial and temporal representations, easy fatigability, unstable emotional and volitional regulation of activity, and other symptoms cause various difficulties in preschool and school education of children with intellectual disabilities. This circumstance determines the need to organize the correctional and pedagogical process in a way that would positively affect the development of psychomotor functions as an integrative component of the entire ontogenetic cycle of a preschooler. There emerges a need to search for new non-traditional instruments for the development of psychomotor functions in preschoolers with intellectual disabilities one of which is correctional eurhythmics. Through a combination of music and special motor and psychological exercises, eurhythmics allow correcting higher mental functions, improving the quality characteristics of movements, and developing personal qualities.

Productive realization of this activity is impossible without high quality organizational and methodical support. However, specialized literature contains little scientific and methodical recommendations on the problem of using musical rhythmic exercises for the development of psychomotor functions in preschool children with intellectual disabilities.

The relevance of said problem determines the goal of the present study which lies in the development of the organizational and methodical basis for the development of psychomotor functions in preschool children with intellectual disabilities through the means of correctional eurhythmics.

Theoretical materials presented in the study complement the data on the stated problem available in the scientific literature and practical relevance of the study is found in the fact that the developmental potential of the developed exercises and games improving general, fine, and articulatory motor skills, cognitive activity, and self-control skills accompanied by the elements of correctional eurhythmics can be useful for teacher-defectologists of preschool education organizations in their professional activity.

\section{Literature review}

The term "psychomotor functions" does not have an unambiguous well-established definition. It is defined as the final element of mental activity determined by the close interconnection between mental processes and movement (Sechenov, 2019); the variability of mentally determined movements of an individual contingent on their sex, age, body structure, etc. (Nikandrov, 2004); a set of consciously performed motor manipulations, a process that 
unites the psyche and its motor expression (Lytaev, Aleksandrov, Berezantseva, 2018); a type of objectification of the psyche in sensorimotor, ideomotor, and emotional-motor (in particular, impulsive) reactions and acts (Platonov, 1986); a set of mental (sensory, intellectual, speech, emotional) and motor qualities (Gurevich, Ozeretskii, 1930), etc.

The definitions of the said concept presented above allow us to summarize its main characteristics and conclude that psychomotor functions present a connection between motor actions and mental processes (cognitive, speech, and emotional and volitional).

The indicated understanding of motor functions provides an opportunity to identify the following main components for its study: the motor, cognitive, and emotional and volitional components accentuated in the present study of preschoolers with intellectual disabilities. It should be noted, however, that the group of children with intellectual disabilities is heterogeneous: it includes not only children with intellectual disabilities whose intellectual deficits are highly pronounced and result from severe damage to the central nervous system but also children whose developmental problems are caused by a defect in the formation of intellectual activity due to mild organic or functional and dynamic disorders of the central nervous system (Puzanov, 2013). The psychomotor development of preschoolers with intellectual disabilities significantly differs from that of their normally developing peers in the motor, cognitive, and emotional and volitional aspects.

In his studies, N. P. Vaizman notes that, compared to the variants of the norm, the process of development of psychomotorics of a child with intellectual disabilities occurs in the course of a more prolonged time period and is not synchronized with the stages of ontogenesis. Such children demonstrate lags in the emergence of age-specific formations and late development of the system of voluntary regulation and the emotional and volitional sphere (Vaizman, 1997).

A. S. Strekalov and E. S. Chernova indicate that the motor sphere of preschoolers with intellectual disabilities is characterized by the lack of formation of visual and motor coordination and underdevelopment of motor functions which manifest in general, fine, facial, and articulatory motor skills. In all children of this category, the development of speech is qualitatively different as poor and stereotyped speech reactions prevent the full use of the verbal means in the consolidation of complex motor acts (Strekalov, Chernova, 2013; Arkhipova et al., 2019).

According to L. I. Kochina and T. N. Senotrusova, the development of the cognitive sphere of children with intellectual disabilities is negatively affected by low cognitive activity, easy fatigability, poor ability to shift the focus of attention, the insufficient formation of spatial representations, the lack of figurative of thinking, and the intuitive nature of thinking (Arkhipova et al., 2019).

A. Zarin, Yu. V. Nefedova believe that the emotional and volitional sphere of preschool children with intellectual disabilities is characterized by the insufficient formation of the process of self-regulation and self-control which are crucial for the development of volitional behavior and the organization of one's activity. Children find it difficult to coordinate the presented rules and requirements with their own actions and give in when any difficulty arises. Such deviations in the emotional sphere as egocentrism, indecisiveness, stubbornness, negativism, and so on cause problems in the organization of social communication and difficulties in communication and, consequently, fuel emotional tension and anxiety (Zarin, Nefedova, 2017).

The listed characteristics of psychomotor functions of preschoolers with intellectual disabilities make the implementation of non-traditional instruments such as correctional eurhythmics for their development relevant. I. G. Borodina and M. A. Kasitsyna define correctional eurhythmics as a type of kinesitherapy (movement therapy) based on the 
interconnection of music, movement, and words in which the rhythm serves as the organizing principle (Borodina, Kasitsyna, 2019).

Many researchers (S. V. Arkhipova, I. G. Borodina, M. A. Kasitsyna, T. V. Kosmacheva, T. S. Ovchinnikova, A. L. Sirotiuk, etc.) indicate that musical rhythmic exercises are highly important to children with intellectual disabilities (Ovchinnikova, 2015; Arkhipova, Kosmacheva, 2018; Sirotiuk, 2009). This conclusion owes to the fact that the features of the motor and mental spheres, the characteristics of activity and behavior, peculiarities of the neuropsychic structure, and emotional-volitional and personal immaturity typically demonstrated by such children are effectively corrected through the specific means of influencing a child characteristic of eurhythmics.

Foreign authors (N. Angelopoulou, A. Mandroukas, K. Neofotistou, M. Sidiropoulou, E. Fotiadou, V. Tsimaras, etc.) note that conscious motor activity is closely connected to the manifestation of psychophysiological functions. The more complex the quality of a movement is, the more it is necessary for a child to engage their cognitive abilities and volitional attention and systematize information received from various analyzers. Thus, the implementation of musical rhythmic means activating the motor activity of children with mild organic or functional and dynamic disorders of the central nervous system allows correcting the defects in their development. On the other hand, the process of development of psychomotor functions through correctional eurhythmics has to be controlled, dosed, and justified (Fotiadou et al., 2019).

Therefore, having become an element in the system of correctional work in a preschool education organization, eurhythmics has a positive effect on the psychophysiological processes in children with intellectual disabilities ensuring the correction of their psychomotor functions through the means of a combination of music and special motor and psychocorrectional exercises.

\section{Materials and methods}

The basis of the study is formed by theoretical methods (analysis of psychological and pedagogical studies on the researched problem), empirical methods (psychological and pedagogical experiment; modeling correctional pedagogical work for the development of psychomotor functions through the means of correctional eurhythmics), and data analysis methods (qualitative and quantitative data analysis).

The first stage of the study involved theoretical analysis of psychological and pedagogical and methodical literature in the course of which we clarified the essence of concepts "psychomotor functions" and "correctional eurhythmics" and identified the specific features of the development of said functions in children with intellectual disabilities. At the second stage of the study, we researched the level of development of psychomotor functions in preschoolers with intellectual disabilities. The third stage of the study comprised the development and realization of experimental work for the development of psychomotor functions in said category of children via the means of correctional eurhythmics, analysis and interpretation of the research data, and the evaluation of its effectiveness.

The experimental work was carried out in the Municipal Preschool Education Institution (MPEI) "Kindergarten No. 65 of a combined type" and MPEI "Kindergarten No. 78 of a combined type" in Saransk (Russia). The study involved 25 children aged from 5 to 6 years having conclusions of psychological, medical, and pedagogical commissions diagnosing them with "Local impaired development. General speech underdevelopment of the 1 st level" or "Diffuse damaged development. General speech underdevelopment of the 2nd level". 
The study of the level of development of psychomotor functions in preschoolers with intellectual disabilities was carried out in three stages involving the study of their motor, cognitive, and emotional and volitional components. The study of the state of the motor component comprised four sessions each of which included 3 to 10 test tasks for the study of general, fine, facial, and speech motor skills. The study of the cognitive component followed E. A. Strebeleva's method (tasks: "Box of forms", "Build from sticks", "Put together the cut picture", "Find the season", "Draw the whole") (Strebeleva, 2019). The emotional and volitional component was studied based on and observation of children's activity in completing new tasks. The results of the diagnostics were calculated in points.

The development of the experimental training method was based on the methods designed by O. M. Garusova, I. S. Morozova, and A. L. Sirotiuk for the development of general, fine, and articulatory motor skills, cognitive activity, and the formation of self-control (Sirotiuk, 2009; Morozova, Garusiva, 2016). We also deployed the elements of correctional eurhythmics based on the following musical materials: P.I. Tchaikovsky's "The Seasons", "Children's Album" performed by A. R. Sevidov, and children's songs and backing vocals.

Particular attention in the correctional eurhythmics lessons was given to the musical accompaniment which included not only rhythmic, stimulating music (march, gallop, polka) but also slow melodies with a calm pattern and phrases accentuating movements, as well as songs with a rhythmic refrain and a smooth solo (waltz, lullabies, music illustrating the murmur of water, the sound of the wind, rain, etc.).

Based on the initial level of development of psychomotor functions, all study participants were divided into two groups (group "A" with the low level, group "B" with the average level) the work with which was carried out differentially through the adaptation of various rhythmic exercises for the individual abilities of children. Lessons were organized in subgroups biweekly and took 20-30 minutes depending on the psychoemotional state of participants. Each lesson with a defectologist included three stages: the preparatory, the main, and the closing.

The first preparatory stage helped children tune in to the upcoming work, reduce anxiety, engage voluntary attention in the process of introductory walking, slow running, and alternating walking, running, jumping, and gallop while observing the clarity of the construction of lines, coordinating the exact beginning of movements and their end with the beginning and end of the music. This stage involved the following musical rhythmic exercises: "Balloon" (optimization of blood circulation and gas exchange); "Lift" (development of voluntary control over breathing); "March" (enrichment and differentiation of sensory information, formation and correction of basic sensorimotor interactions), etc.

The second, main part included exercises for the development of psychomotor functions (general, fine, and speech motor skills; spatial perception, attention, memory; volitional qualities: independence, perseverance, etc.), such as: "Peepers" (expanding the field of vision, improving visual perception); "Angry kitty" (for the development of mobility of the muscles of the back of the tongue); "Fingers say hello" (for the development of fine motor skills, coordination of movements of fingers); "We froze in the cold" (activating the full exchange of information between the right and left hemispheres, forming a functional connection between both hemispheres), etc.

The third closing stage was aimed at relaxing and raising the mood with musical accompaniment combined with the ritual of farewell. The closing stage included the following musical rhythmic exercises: "Fat man" (to relieve tension from the muscles of the upper and lower limbs); "Smile and wave" (to dispel negative emotions); "Smells of flowers" (to relax), etc. 
The inclusion of musical rhythmic exercises in the correctional process was also carried out in stages.

At the first stage, preschoolers were introduced to the main types of movements of a specific exercise, and the motivation for completing it was formed. These exercises were aimed at preparing study participants for completing more complex exercises. Naming exercises introduced at the first stage created conditions for the formation of its image and certain associations which activated the work of the central nervous system of preschoolers with intellectual disabilities.

The second stage involved learning the exercises in-depth, clarifying the motions and the technique of completing them, and bringing the children closer to understanding the patterns of movement. The success of work depended on skillful prevention and correction of mistakes during multiple repetitions of the exercises resulting in the improvement of the rhythm and continuity of their execution. At this stage, the preschoolers still relied on the defectologist's demonstrations although they already strove to complete rhythmic elements and compositions independently.

The third stage was devoted to the consolidation and improvement of motor skills in performing musical rhythmic exercises. The formation of a motor skill transitioning to partial creative self-expression in moving to music was taking place. The pattern of movements was becoming more complex and the pace was increasing. More often, the defectologist only used the name of the exercise without demonstrating it.

\section{Results}

In this section of the article, we shall examine the results of the ascertaining experiment focused on identifying the level of development of psychomotor functions in preschoolers with intellectual disabilities.

The examination of the state of the motor component showed that $44 \%$ of the study participants were unable to maintain balance, coordinate their movements while jumping, and roll a napkin into a ball with one hand - their movements were sluggish, not fixated, disinhibited. However, 56\% of children were able to complete the tasks partially: the movements were fixated for a short period of time, were imprecise, their strength was quickly depleted; $24 \%$ of preschoolers could not fixate mimic poses, and $76 \%$ of the participants who succeeded showed slow pace in completing the tasks, instability of the pose, and low level of self-control. In $44 \%$ of children, the movements of the articulation organs were weak or tense. It should be noted that $56 \%$ of preschoolers completed the movements of the first tasks precisely, however, by the end of a session their movements were also becoming slow and imprecise and children made efforts and accompanying movements to maintain the pose. Only $36 \%$ of the participants partially or minimally mastered the fine movements of fingers. The movements of most children $-64 \%$ - were characterized by disinhibition and indistinctness, their attention was unstable, and self-control was lacking.

The examination of the cognitive component demonstrated that in most cases (64\%), preschoolers did not show interest in the tasks and did not complete cognitive tasks; their speech only contained individual words or basic phrases. The children were unable to concentrate and keep their attention focused on a specific task; they experienced difficulties navigating in space. Some tasks they refused to complete. Only $36 \%$ of the participants were completing tasks with an experimenter's assistance, needed reiteration of instructions, tips, and demonstrations. In the process of independent completion of cognitive tasks, non-productive actions prevailed since the subjects performed tasks intuitively without delving into the essence of the proposed task. In the children's speech, gross violations of the lexical and grammatical structure, sound pronunciation, and syllabic structure of words were detected. 
The examination of the state of the emotional and volitional component revealed that $64 \%$ of the study participants positively reacted to toys, easily made contact with an adult, and showed interest during communication. However, once faced with minor difficulties, they were easily losing interest, found it difficult to find and correct their mistake, their mood worsened; some children demonstrated aggression and refused further interaction reacting to a failure; $36 \%$ of the sample was constituted by preschoolers who were indifferent to completing new tasks, they often became distracted, tried to change the subject to a topic of interest to them but still returned to the task again. They were unable to find and correct their mistakes independently and corrected them uncritically when prompted.

Considering the results of the study, we divided the participants into two differentiated groups "A" and "B".

Group "A" - preschoolers with the low level of development of psychomotor functions - was characterized by the lack of coordination in the movements of hands, legs, fingers, and tongue; sluggish, constrained, imprecise nature of movements; low level of development of visual orientation, holistic perception, and visual and figurative thinking; performing tasks following an example or a demonstration; unstable attention, weak memory, and lack of selfcontrol.

Group "B" - preschoolers with the average level of development of psychomotor functions - was characterized by quick exhaustion of the strength of movements, poor coordination of the muscles of arms, legs, fingers, and tongue; the average level of development of holistic perception, visual and figurative thinking, and visual orientation; unstable attention and poor self-control.

The percentage ratio of said groups of preschoolers by the levels of development of psychomotor functions is demonstrated in Figure 1.

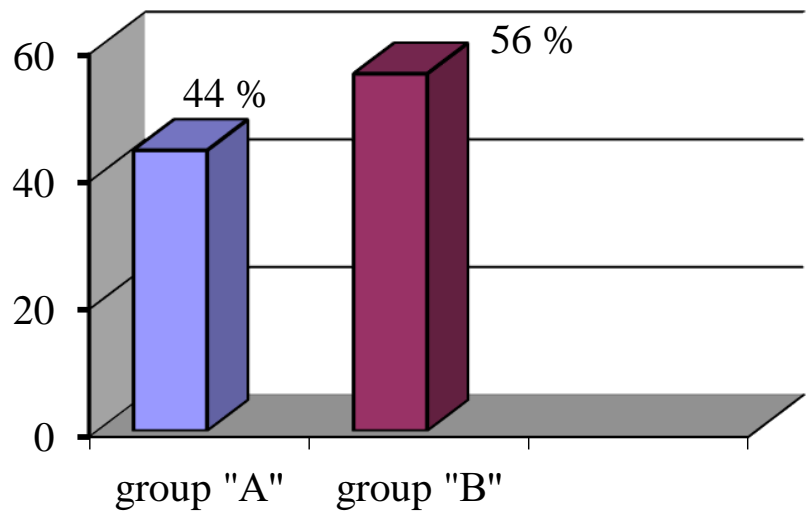

口The low level of formation of psychomotor functions

口The average level of formation of psychomotor functions

(Figure 1): Distribution of preschoolers with intellectual disabilities by the levels of formation of psychomotor functions (as a result of the ascertaining experiment)

Let us examine the results of the control experiment testing the effectiveness of experimental work on developing psychomotor functions in preschool children with intellectual disabilities using the means of correctional eurhythmics. 
Examination of the motor component showed that $36 \%$ of the participants successfully completed all the tasks testing general voluntary motor skills: their movements were precise and articulate and a moderate pace of completion of tasks prevailed. $40 \%$ of the sample group completed the tasks to the minimum extent - the children maintained balance, successfully coordinated their movements while jumping, and were able to roll a napkin into a ball with one hand, however, the strength of their movements was quickly depleted and the children had difficulty maintaining balance. Only $24 \%$ of the preschoolers were unable to coordinate their movements, were completing the tasks slowly and imprecisely, and used accompanying movements.

Moreover, $76 \%$ of the children succeeded in all the proposed tasks examining the state of voluntary mimic motor skills: their facial expressions were notably lively and the tasks were performed at a moderate and fast pace. $24 \%$ of the subjects completed all the presented tasks but not to the full extent. In $52 \%$ of the preschoolers, verbal motor skills were characterized by sluggishness and imprecision, however, $48 \%$ of the group performed the movements legibly and accurately at a moderate pace. It should also be noted that $64 \%$ of the children demonstrated a good mastery of the fine movements of fingers and only $36 \%$ of them completed the proposed tasks with effort and not fully.

Examination of the cognitive component allowed us to establish that $36 \%$ of the study participants were unable to complete the tasks or refused to do so and their speech predominantly consisted of basic phrases and monosyllabic answers. The children needed direct assistance from an adult. Independent completion of tasks with or without learning how to do it was available to $64 \%$ of the children. They showed interest and willingly engaged in cooperative activities with an adult. The students attempted to complete the proposed tasks on their own, received the experimenter's assistance when facing difficulties, and tried to reply with detailed answers, however, their speech contained violations of the grammatical structure, the syllabic structure of words, and pronunciation.

Examination of the emotional and volitional component demonstrated that $44 \%$ of the children willingly engaged in completing new tasks, worked on them intently, strove to complete them without resorting to an adult's assistance, rejoiced at their successes, and adequately reacted to mistakes trying to correct them; $28 \%$ of the subjects engaged in completing new tasks reluctantly, were often getting distracted but returned to the tasks and accepted the teacher's assistance in case of difficulties. However, $28 \%$ of the preschoolers demonstrated an unwillingness to engage in work, refused to do it, exhibited violent negative emotions at the sight of first difficulties, while some children, on the contrary, became closed, showed indifference, and refused an adult's help trying to avoid completing the tasks.

After the experimental training, all the study participants were divided into three differentiated groups "A", "B", and "C".

Group "A" - with the low level of development of psychomotor functions - is characterized by the low level of development of coordination of the movements of arms, legs, fingers, and tongue; the low level of development of visual orientation, holistic perception, and visual and figurative thinking; completing the tasks following a demonstration; poor memory, attention span, and self-control.

Group "B" - with the average level of development of psychomotor functions - is characterized by the rapid exhaustion of the strength of movements, poor coordination of arms, legs, fingers, and tongue; the average level of development of holistic perception, visual and figurative thinking, and visual orientation; completing the tasks following a demonstration; unstable attention and self-control. 
Group "C" - with the high level of development of psychomotor functions - is characterized by well-coordinated movements of arms, legs, fingers, and tongue; unrestrained, confident, precise movements; the high level of development of visual orientation, holistic perception, and visual and figurative thinking; independent completion of the tasks; stable attention and well-developed memory and self-control.

The positive dynamic of the development of psychomotor functions in preschoolers with intellectual disabilities after the conducted experimental training is demonstrated in Figure 2.
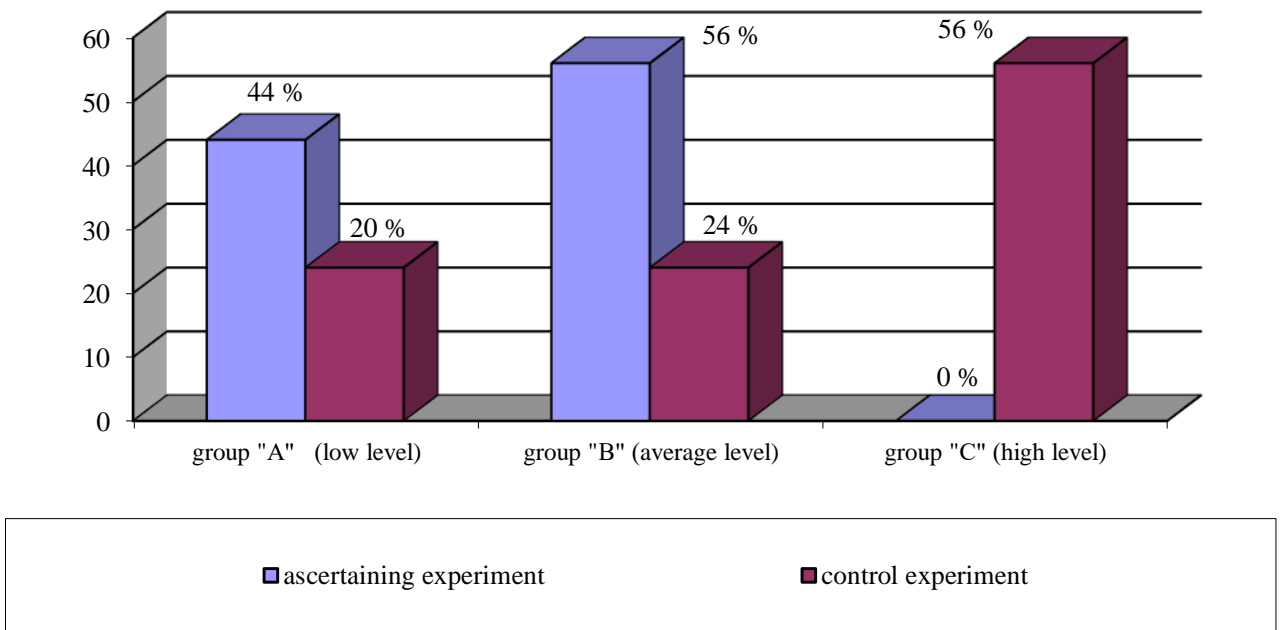

(Figure 2): Distribution of preschoolers with intellectual disabilities by the levels of formation of psychomotor functions (as a result of the control experiment)

Based on the data obtained as a result of the ascertaining and control experiments carried out before and after the experimental training using the means of correctional eurhythmics, we can trace a positive dynamic in the development of psychomotor functions in preschoolers with intellectual disabilities. The presented analysis demonstrates that the number of children at the low level of development of psychomotor functions decreased by half, the quantitative indicators at the average level decreased by three times, and the high level of development that was not detected in the examined students before the experimental training was diagnosed in more than half of the study participants.

\section{Discussion}

The present study was aimed at the development of an organizational and methodical foundation for the development of psychomotor functions in preschool children with intellectual disabilities using the means of correctional eurhythmics. The obtained results are consistent with the studies conducted by N.P. Vaizman, A. Zarin, S.Iu Ilina, L.I. Kochina, Yu.V. Nefedova, T.N. Senotrusova, A.S. Strekalova, M.A. Chebotova, E.S. Chernova, and others (Vaizman, 1997; Strekalov, Chernova, 2013; Arkhipova et al., 2019; Kochina, Senotrusova, 2016; Zarin, Nefedova, 2017) and show the inconsistency of the psychomotor development of children from said category with the stages of ontogenesis. Their motor sphere is characterized by the rapid exhaustion of the strength of movements and poor coordination of the muscles of arms, legs, fingers, and tongue. This observation supports the conclusion made by A. S. Strekalova and E. S. Chernova stating that the preschoolers of this category are unable to execute movements in strict accordance with the spatial, temporal, and dynamic characteristics.

The cognitive component of the psychomotor functions of the examined category of preschoolers demonstrates concreteness, the lack of formation of holistic perception, visual and 
figurative thinking, and visual orientation, and the instability of attention. These conclusions are also reflected in the works of L. I. Kochina and T. N. SenotrusovajError! Marcador no definido. in which preschoolers with intellectual disabilities are characterized by the reduced cognitive activity, the elements of infantilism, impulsivity or slowness of cognitive actions, and the insufficient formation of the basic cognitive operations which manifest to the greatest extent at the verbal level.

In the process of the experimental work, deficiencies in the emotional and volitional component of mental functions manifesting in the underdevelopment of the processes of selfregulation and self-control of movements, speech, and behavior were observed. Similar conclusions were reached by A. Zarin, Yu. V. Nefedova;Error! Marcador no definido. who diagnosed the examined preschool children with intellectual disabilities with the delayed development of the regulatory component reflected in their inability to allocate their mistakes, the increase in the number of errors by the end of the work, and the requirements for the work not being fully met.

The results of the conducted study align with the views of S. V. Arkhipova, T. V. Kosmacheva, T. S. Ovchinnikova, and others (Ovchinnikova, 2015; Arkhipova, Kosmacheva, 2018) who note that musical rhythmic exercises have a positive effect on the development of psychomotor functions in preschoolers with disabilities including intellectual disabilities. We believe this to be associated with the features of motor and cognitive development, the specificity of activity and behavior, and the emotional and volitional and personal immaturity characteristic of such children being susceptible to correction through the specific means of influencing a child inherent in eurhythmics.

\section{Conclusion}

The issues of psychomotor development of preschoolers with disabilities via the means of correctional eurhythmics present a relevant direction of modern research. However, children with intellectual disabilities often fall outside the scope of musical and rhythmic work due to the specific characteristics of their defects. The conducted experimental work supports the proposed hypothesis stating that the process of development of psychomotor functions in said category of preschoolers is negatively affected not only by the characteristics of their psychophysical development but also by the shortcomings of traditional learning. Therefore, it seems plausible to include the elements of correctional eurhythmics in the work on the development of psychomotor functions. This proposition illustrates the results of the ascertaining and control experiments presented in Figures 1 and 2.

The conducted experimental study aimed at improving the process of development of psychomotor functions in preschool children with intellectual disabilities comprised the development of games and exercises including the elements of correctional eurhythmics adapted for the children of this category and their practical implementation in musical rhythmic lessons. The analysis of the results of the experiment demonstrates a positive dynamic in the development of psychomotor functions of the study participants which supports the effectiveness of the conducted work.

The materials of the present study may be of use to the specialists and teachers of preschool education organizations who are interested in the development of psychomotor functions in preschoolers with intellectual disabilities. Directions for further research in this subject area include expanding the spectrum of the studied deviations in the development of children with disabilities and the correctional influence produced on them by musical and rhythmic work.

\section{Acknowledgments}


The study was conducted with the financial support of a partner university the Federal

State Budgetary Educational Institution of Higher Education "I. Yakovlev Chuvash State Pedagogical University" on the topic "The use of correctional and developmental technologies in the development of psychomotor functions in preschool children with disabilities" (No. 35/2020, registration date: April 16, 2020).

\section{Referencias}

Arkhipova, S.V., Bartsaeva, E.V., Bobkova, O.V., Vinokurova, G.A., Zolotkova, E.V., Lavrentieva, M.A., Ryabova, N.V., Babushkina, L.E. (2018). Professional development and employment promotion of persons with disabilities and limited health capacities. Ponte, 74(3/1), 305-319.

Arkhipova, S.V., Grishina, O.S., Minaeva, N.G., Mikheikina, T.A., Ryabova, N.V. (2019). The formation of the coherent speech of junior schoolchildren with intellectual disabilities by means of animation-based therapy. Revista Inclusiones, 6(Especial), 47-62.

Arkhipova, S.V., Kosmacheva, T.V. (2018). Formirovanie psikhomotornykh navykov u doshkolnikov s umstvennoi otstalostiu sredstvami korrektsionnoi ritmiki. Problemy sovremennogo pedagogicheskogo obrazovaniia, 59-3, 33-37.

Bobkova, O.V., Gamajunova, A.N., Abramova, I.V., Zolotkova, E.V. (2019). Conditions of adaptation to the higher education process in students with disabilities and limited health capacities. La Prensa Médica Argentina, 105(9), 509-521.

Borodina, I.G., Kasitsyna, M.A. (2019). Korrektsionnaia ritmika: kompleks prakticheskikh materialov i tekhnologiia raboty s detmi starshego doshkolnogo vozrasta. Moscow: Gnom i D.

Fotiadou, E., Neofotistou, K., Sidiropoulou, M., Tsimaras, V., Mandroukas, A., Angelopoulou, N. (2019). The effect of a rhythmic gymnastics program on the dynamic balance ability of individuals with intellectual disability. Journal of strength and conditioning research, 23, 2102-2106.

Gurevich, M.O., Ozeretskii, N.I. (1930). Psikhomotorika. Moscow: Gos. med. izd.

Kochina, L.I., Senotrusova, T.N. (2016). Razvitie poznavatelnoi aktivnosti u uchashchikhsia s umerennoi umstvennoi otstalostiu $\mathrm{v}$ protsesse organizatsii proektnoi deiatelnosti. Psikhologiia i pedagogika: metodika i problemy prakticheskogo primeneniia, 48, 123127.

Lytaev, S.A., Berezantseva, M.S., Aleksandrov, M.V. (2018). Psikhofiziologiia: uchebnoe posobie. Moscow: SpatsLit.

Morozova, I.S., Garusiva, O.M. (2016). Psikhomotornoe razvitie doshkolnikov: tsikl zaniatii. Moscow: Natsionalnyi knizhnyi tsentr.

Nikandrov, V.V. (2004). Psikhomotorika: uchebnoe posobie. St. Petersburg: Rech.

Ovchinnikova, T.S. (2015). Metod korrektsionnoi ritmiki v vospitanii doshkolnikov s ogranichennymi vozmozhnostiami zdorovia. Bulletin of the Pushkin Leningrad State University, 2, 105-112.

Platonov, K.K. (1986). Struktura i razvitie lichnosti: psikhologiia lichnosti. Moscow: Nauka.

Puzanov, B.P. (2013). Obuchenie i vospitanie detei s intellektualnymi narusheniiami. Moscow: Vlados.

Sechenov, I.M. (2019). Fiziologiia nervnoi sistemy. Moscow: IURAIT.

Sirotiuk, A.L. (2009). Uprazhneniia dlia psikhomotornogo razvitiia doshkolnikov: prakticheskoe posobie. Moscow: Arkti.

Strebeleva, E.A. (2019). Psikhologo-pedagogicheskaia diagnostika razvitiia detei rannego i doshkolnogo vozrasta: metod, posobie s pril. alboma "Nagliadnyi material dlia obsledovaniia detei". Moscow: Prosveshchenie.

Strekalov, A.S., Chernova, E.S. (2013). Differentsiatsiia detei starshego doshkolnogo vozrasta s intellektualnymi narusheniiami na odnorodnye gruppy po urovniu razvitiia dvigatelnykh i poznavatelnykh sposobnostei. Gaudeamus, 1, 129-134.

Vaizman, N.P. (1997). Psikhomotorika umstvenno otstalykh detei: uchebnoe posobie. Moscow: Agraf. 
Zarin, A., Nefedova, Yu.V. (2017). Dinamika emotsionalno-volevoi sfery i povedeniia doshkolnikov s intellektualnoi nedostatochnostiu. In: Sultanov K V (ed.) Prazdniki i povsednevnost $\mathrm{v}$ zhizni osobogo rebenka: materialy XXIV Mezhdunarodnoi konferentsii "Rebenok v sovremennom mire. Detstvo: Prazdnik i povsednevnost". St. Petersburg: Publishing House of Herzen State Pedagogical University of Russia. 